\title{
Constitutional Reform in the UK: A Note on the Legacy of the Kilbrandon Commission
}

\author{
Gary Wilson ${ }^{1}$
}

Published online: 12 September 2017

(C) The Author(s) 2017. This article is an open access publication

\begin{abstract}
The past two decades have seen large shifts in the constitutional landscape of the United Kingdom. This began with the devolution of powers from Westminster to Scotland, Wales and Northern Ireland under the first Blair government. More recently, the localism agenda advanced by the Coalition and subsequent Conservative governments has sought to further devolve powers to areas within England, and the constitutional integrity of the UK itself was threatened by 2014s Scottish independence referendum and the 2016 referendum vote for the UK to leave the European Union. It is convenient to regard constitutional reform concerned with the dispersal of power through the creation of new executive and legislative bodies as a modern phenomenon. However, the roots of devolution go back much further. Largely forgotten is the work of the Kilbrandon Commission, established to consider the allocation of executive and legislative power within the UK, which reported in 1973 and effectively produced the first substantial proposals for the devolution of power from Westminster. Almost two decades on from the creation of the devolved institutions for Scotland, Wales and Northern Ireland, the present moment is as opportune as any to consider the longer-term legacy of the Kilbrandon Commission. This note revisits the major findings and recommendations of Kilbrandon and attempts to consider the extent to which these have been realised in subsequent constitutional reform initiatives. While difficult to quantify its significance, it is nonetheless important to recognise the relevance of the commission's work for subsequent and unfinished developments within the area of constitutional reform.
\end{abstract}

Keywords Constitutional reform · Devolution · Kilbrandon Commission

Gary Wilson

G.Wilson@ljmu.ac.uk

1 Liverpool John Moores University, Liverpool, UK 


\section{Introduction}

The unprecedented scale of constitutional change witnessed in the period since 1997 might lead to the assumption that pressures for constitutional reform have only emerged relatively recently. This would be a mistake. Although undoubtedly these pressures intensified and found favour especially under the Labour government which entered office in 1997, their origins go back much further and it was under an earlier Labour government that a royal commission was established in the late 1960s to specifically probe matters concerning the allocation of power within the United Kingdom between central government and the UK's constituent parts. The Kilbrandon Commission reported in 1973, although its very existence, not to mention its proposals - which did not meet with unanimity on the part of its membership — has largely become a mere footnote in constitutional history. ${ }^{1}$ This is unfortunate given that the Commission's discussions touched upon the very kinds of issues revisited a quarter of a century later when measures to effect devolution to Scotland, Wales and Northern Ireland were implemented, and to a lesser extent when ill-fated proposals for regional government within England were formulated shortly thereafter. More recent developments, including Scotland's 2014 independence referendum and initiatives to devolve greater powers on combined local authorities and elected mayors within England, mean that there has not been a more opportune time to revisit the findings of the Kilbrandon Commission in order to assess its longer term significance for the constitutional reform agenda.

This note begins by briefly detailing the traditional constitutional structure of the United Kingdom and the pressures for devolution which resulted in the creation of the Kilbrandon Commission. It then outlines the remit of the Kilbrandon Commission, before proceeding to consider its longer-term legacy. In so doing, attention is given to the Commission's discussions in four main regards: notions of national or regional identity; devolution to the UK's constituent parts; devolution to the English regions; and missed opportunities to further wider constitutional reform causes.

\section{The Traditional Constitutional Structure of the United Kingdom}

In historic terms, the present day United Kingdom is a relatively recent creation. ${ }^{2}$ As one scholar has explained, it "was not the political outcome of a grand political design to unite the peoples of the British Isles within a common realm [but] a contingent outcome of a cumulative process of political integration over centuries, primarily, though not exclusively, determined by English interests and statecraft." 3 While England and Wales had been administered jointly since the mid-sixteenth century, ${ }^{4}$ union between England and Scotland did not occur until the 1707 Act of

\footnotetext{
1 For a rare contemporary discussion of the commission's report, see Daintith (1974).

2 On the early development of the United Kingdom, see Colley (2009).

3 O’Neill (2004: 13).

${ }^{4}$ As a result of the Acts of Union of 1536 and 1543, more accurately titled the Laws of Wales Acts.
} 
Union. ${ }^{5}$ The 1800 Acts of Union united the three constituent parts of Great Britain and Ireland within the United Kingdom, although Ireland had essentially been colonised by English monarchs at least as far back as Tudor times. ${ }^{6}$

Until the later part of the twentieth century, the only constituent part of the UK which had posed any significant constitutional challenge to the territorial integrity of the UK was Ireland, much of the population of which had always been reluctant subjects of the British Crown. Economic depression in the province in the aftermath of the potato famine of the mid nineteenth century accelerated the backlash against British rule. The cause of Irish home rule began to be taken seriously during the 1880 s and 1890s, and it was under the premiership of William Gladstone that attempts to confer home rule upon Ireland first occurred. ${ }^{7}$ Although finally legislated upon in $1914,{ }^{8}$ home rule was placed on hold when the First World War broke out, and uprisings against British rule escalated into an Irish war of independence. ${ }^{9}$ Although the partition of Ireland into two under the terms of the Government of Ireland Act 1920, with separate devolved parliaments envisaged for North and South, was intended to address tensions between the republican and unionist factions, these provisions were never realised. The 1921 Anglo-Irish Treaty provided for Irish independence while the six counties in the North remained part of the UK as Northern Ireland. ${ }^{10}$ Endowed with its own Parliament, Northern Ireland enjoyed the "trappings of a semi-independent state", ${ }^{11}$ although as the province's 'troubles' began to worsen and relations between its political factions entered a state of deterioration, its devolved institutions were suspended and Northern Ireland fell under direct rule from London from 1972 onwards. ${ }^{12}$

Although a conference convened by the Speaker of the House of Commons in 1919 gave some consideration to the possible devolution of legislative and executive powers, ${ }^{13}$ with the exception of Northern Ireland, the UK would not experience any devolution of powers to its constituent parts until the end of the twentieth century. It has, thus, functioned essentially as "the largest unitary state among stable democracies," 14 with all executive and legislative powers invested in the UK government and Westminster Parliament. Within this framework, functions specific to the UK's constituent parts have been performed by dedicated

\footnotetext{
5 On the features of the Act of Union, see Devine (2012: ch.1). For a perspective on Scotland's history as part of the UK, see Lord Sumption (2014).

${ }^{6}$ See Ferguson (2003: 55-57); Killeen (2012: 38-149).

7 See Ferguson (2003: 55-57); Bogdanor (1999: 19-54).

${ }^{8}$ Government of Ireland Act 1914.

9 See Killeen (2012: 246-254).

${ }^{10}$ On the developments leading to Irish independence, see Hadfield (2003: 591-604).

11 Brazier (1999: 97 et seq).

12 For an overview of devolution to Northern Ireland, see Bogdanor (1999: 55-109).

13 The conference met 32 times before ending in stalemate. On its work, see Evans (2015: 25-6).

14 Bogdanor (1999: 1).
} 
departments of state. ${ }^{15}$ Pressures for Scottish home rule began in the second half of the nineteenth century, with a number of bills promoting this objective being introduced in Parliament, although not making any real progress. ${ }^{16}$ This coincided with what has been described as "a decisive movement towards the creation of a more centralised British state." 17 Unlike Wales, Scotland has throughout its membership of the union retained and operated its own legal, educational, and religious systems, ${ }^{18}$ and in the view of Rodney Brazier, "That long history of Scottish institutions, in the main unaffected by the union, must help to explain why nationalist, or at least devolutionary, sentiment has been stronger in Scotland than in Wales." 19 The Scottish Home Rule Association was founded in 1886 and the Liberal Party took up the cause of home rule shortly thereafter, while the Scottish Nationalist movement underwent various incarnations and transformations from the late nineteenth century onwards, culminating in the creation of the Scottish National Party in $1934 .^{20}$ The party initially only enjoyed limited support, however, while Welsh nationalism was an even weaker force. Although Plaid Cymru was created in 1925 , there has never been the level of support for the devolution of power to Wales that there has for Scotland. ${ }^{21}$ Pressures for the devolution of power to the UK's constituent parts, in particular Scotland, ${ }^{22}$ intensified from the 1960 s onwards, ${ }^{23}$ with then Conservative leader Edward Heath the first major party leader to express support for any measures of devolution when advocating the creation of a Scottish Assembly in his 1968 Declaration of Perth.

\section{The Kilbrandon Commission}

The creation of the Royal Commission on the Constitution by Harold Wilson's Labour government in April 1969 came in response to a perceived growth in support for nationalist causes in Scotland and Wales, fuelled by Plaid Cymru's capture of its first ever parliamentary seat in the 1966 Camarthen by-election and the SNP's similarly spectacular victory the following year in the Hamilton by-election. Constituted initially under the chairmanship of Lord Crowther, it was only following his death 3 years later that the commission became the "Kilbrandon

\footnotetext{
15 The Scottish Office was established in 1885, the Welsh Office in 1965. The Northern Ireland Office as created in 1972 to take over the functions previously exercised by the devolved by the Northern Irish government.

16 See Brown (2014: 142-167); Devine (2012: 307).

17 Brown (2014: 158).

18 See Devine (2012: chs.5, 16-17).

19 Brazier (2007: 109).

${ }^{20}$ On the development of the Scottish Nationalist movement, see the Kilbrandon Commission report, vol,1, paras.339-346.

21 On the development of the Welsh Nationalist movement in the early twentieth century, see the Kilbrandon Commission report, vol.1, paras.347-356. See also Evans (2006).See also Bogdanor (1999: 144-165).

22 See Devine (2012: 574-590).

23 On developments leading to devolution to Scotland and Wales, see Leicester (1999: 251-263).
} 
Commission", when his place was taken by Lord Kilbrandon. It has been noted that the creation of a royal commission is the "favoured expedient of a harassed administration," 24 and it is in this vein that the creation of the commission can be seen as an attempt to demonstrate a degree of government responsiveness to growing pressures for the devolution of power while avoiding the need to address this with any immediate measures at a time when the governing Labour party had not reached any consensus itself on such questions.

With an implicit mission to consider the creation of mechanisms which might stem any potential growth in the tide of nationalism, the Commission's broadly worded terms of reference were "to examine the present functions of the central legislature and government in relation to the several countries, nations and regions of the U.K." 25 The majority of the commission interpreted their terms of reference relatively narrowly to focus on the possible devolution of power to the countries and regions of the UK, and to consider whether any changes to constitutional and economic relationships within the UK were desirable. ${ }^{26}$ The dissenting minority felt, however, that the commission had a wider remit than this and extended their consideration to the functioning of Parliament and political parties. ${ }^{27}$ However, there was a degree of consensus in respect of the principles by which the commission's work should be guided, both majority and minority reports emphasising the importance of preserving the political unity of the UK. ${ }^{28}$ There was also shared acknowledgment of perceived public distrust of government and dissatisfaction with the functioning of democracy. ${ }^{29}$

The members of the commission were unable to reach any consensus upon the substantive recommendations which they would make, two members taking the unusual step of publishing their findings in a separate volume to the report. ${ }^{30}$ Even the main body of the report represented "a diffuse and long-winded document in which it is difficult to disentangle the essential arguments." ${ }^{31}$ The Kilbrandon report was briefly debated in Parliament, ${ }^{32}$ but quickly appeared to have been consigned to the archives and conveniently forgotten about. In spite of this, consideration of the report nearly a half century later in the post-devolution era demonstrates a longer term legacy, in particular in signposting the desirability of certain constitutional reforms which have come to be implemented or continue to feature on the constitutional reform agenda. For present purposes, we consider the legacy of the

\footnotetext{
${ }^{24}$ Bogdanor (1999: 171).

25 Kilbrandon Report (1973: Vol.I, para.11).

26 Kilbrandon Report (1973: Vol.I, para.13).

27 Kilbrandon Report (1973: Vol.II, ch.1).

28 Kilbrandon Report (1973: Vol.I, para.393; Vol.II, paras.126-128). General guiding principles were, however, outlined in greater detail within the main report and involved the retention by Parliament of its supreme authority; avoidance of attempts to create a new constitution in entirety; the need to adhere to the wishes of the population; and regard for pragmatism. See Vol.I, infra, ch.11.

29 Kilbrandon Report (1973: Vol. I, paras.296-323; Vol.II, paras.34-35).

30 Volume II. For a brief summary see 'Dissenters urge plan for seven assemblies', The Times, 1 November 1973 , p.5.

31 Bogdanor (1999: 173).

32 HC Deb, 31 October 1973, vol 863, cc163-175.
} 
Kilbrandon Commission under four principal headings: notions of national or regional identity; devolution to Scotland, Wales and Northern Ireland; devolution to the English regions; and missed opportunities to further wider constitutional reform. ${ }^{33}$

\section{The Legacy of the Kilbrandon Commission}

\section{National or Regional Identity}

The relevance of perceptions of identity to pressures for devolution were central to the discussion contained in the Kilbrandon report, which alluded to evidence of growing support for nationalist parties in Scotland and Wales as a central factor in its creation. The report made observations in respect of Scotland and Wales which pointed to a strong sense of national identify, such as that "the cultural and social attitudes of Scotland have in the past differed quite markedly," 34 and "there remains a strong sense of Welsh identity, a different way of looking at things and a distinct feeling that the needs and interests of people in Wales must be considered separately from those of people elsewhere in the UK." ${ }^{35}$ By contrast, it was implied that any distinct English national identity was much weaker, it being noted that, "There is no English nationalist movement." 36 Whereas Scottish and Welsh pressures for devolution might be rooted in their minority status within the UK, equivalent pressures were not detected in England, it being suggested that, "Probably because of its dominant position in the UK, there has been no demand for the creation of institutions of government to serve England as a whole or particular parts of it comparable to the demands made in Scotland and Wales." ${ }^{37}$ The perception that stronger demands for devolution existed in Scotland and Wales than was the case in England undoubtedly informed the proposals advanced by the majority of the Kilbrandon Commission, which centred on legislative devolution for Scotland and Wales, but only more minimal devolved powers for English regions. ${ }^{38}$ There was also greater support for legislative devolution to Scotland than Wales, ${ }^{39}$ reflecting the belief that Scotland was the more favourable of the two countries towards the introduction of such measures. Although the dissenting minority cited polling data which suggested that the Scottish were only marginally more favourable to devolution than the populations of a number of English regions, ${ }^{40}$ the majority's assessment of feelings of national and regional identity has been reinforced in most subsequent efforts to implement devolution within the UK. These are touched upon

\footnotetext{
33 For a contemporaneous overview of the Kilbrandon report, see Daintith (1974).

34 Kilbrandon Report (1973: vol.I, para.86).

35 Kilbrandon Report (1973: vol.I, para.130).

36 Kilbrandon Report (1973: vol.I, para.185).

37 Kilbrandon Report (1973: vol.I, para.225).

38 See below.

39 Kilbrandon Report (1973: vol.I, para.1123).

${ }^{40}$ Kilbrandon Report (1973: vol.II, para.65).
} 
in greater detail in the sections which follow, but two points are particularly important to make at this stage. Firstly, devolution initiatives have focused upon the creation of institutions of government for Scotland and Wales (and from the late 1990s, Northern Ireland) rather than for England or its regions. This was true of both the devolution legislation introduced in the late $1970 \mathrm{~s}^{41}$ and that successfully enacted in $1998 .^{42}$ Although the Blair government would toy with proposals for directly elected regional assemblies, ${ }^{43}$ this initiative was soon scuppered in the face of lacking public enthusiasm after the North-East of England overwhelmingly rejected the creation of an assembly for their region. ${ }^{44}$ Opinion polls have only indicated minimal support for the creation of English regional assemblies. ${ }^{45}$ Secondly, from Kilbrandon onwards there has always been recognition of a greater Scottish desire for robust devolved powers. The referendum votes on devolution held in both 1979 and 1997 reinforced this, ${ }^{46}$ and in devolution measures to have been introduced, Scotland has always been bestowed with a greater level of autonomy. ${ }^{47}$ That Scotland came close to voting for independence in 2014 further reinforces the gulf in nationalist aspirations between Scotland and Wales. ${ }^{48}$

\section{Devolution to Scotland and Wales}

The crux of the Kilbrandon proposals centred on the devolution of power to Scotland and Wales, although there was a notable difference between the approach taken in the majority and minority reports. While the minority rejected legislative devolution for Scotland or Wales in favour of a more uniform system of administrative devolution to seven national or regional assemblies, ${ }^{49}$ the majority report advocated a system of Scottish and Welsh devolution which resembled in large part subsequent legislative proposals and the eventual measures implemented

\footnotetext{
41 See Scotland Act 1978, Wales Act 1978.

42 See Scotland Act 1998, Government of Wales Act 1998, Northern Ireland Act 1998.

43 See UK Government (2002).

44 See 'North east votes 'no' to assembly', BBC News Online, 5 November 2004, available at http:// news.bbc.co.uk/1/hi/uk_politics/3984387.stm.

45 See, eg., McKay Commission (2013: 18), Curtice (2006: 121).

$4651.6 \%$ of Scots backed devolution in 1979 compared to just $20 \%$ of Welsh voters supporting devolution at the same time. By 1997, 74\% of Scots supported devolution compared to just $50.3 \%$ of Welsh voters.

47 For example, while Scotland's Parliament has always enjoyed primary legislative powers, the Welsh Assembly did not initially enjoy such powers. The Scottish Parliament is also empowered to vary the rate of income tax within Scotland, which the Welsh Assembly is not. The legislative competence of the Scottish Parliament also extends further than that of the Welsh Assembly.

48 Scotland's electorate rejected independence by a 55-45\% margin, although the pro-independence campaign did lead in some opinion polls towards the end of the referendum campaign. See 'Scottish independence: Vote 'will go to the wire', BBC News Online, 7 September 2014, available at http://www. bbc.co.uk/news/uk-scotland-29096458.

49 The minority were motivated by the perceived need to maintain political equality throughout the UK and proposed seven democratically elected assemblies endowed with weaker, purely administrative powers, to represent Scotland, Wales and five English regions. See Kilbrandon Report (1973: vol.II, preface \& ch.6).
} 
by the government of Tony Blair a quarter of a century later. Although disagreed on the extent of the powers which should be devolved, ${ }^{50}$ eight members signing the majority report supported the creation of a Scottish assembly endowed with legislative powers. ${ }^{51}$ While there was also broad support for the creation of a Welsh assembly, only six members felt that it should enjoy the power to legislate, ${ }^{52}$ two others believing that it should only exercise delegated powers or advisory functions. ${ }^{53}$ For each country, a hundred member unicameral body elected under the single transferrable vote for 4 year terms was proposed from which a cabinet would be drawn to exercise executive powers devolved from central government. ${ }^{54}$ In light of the fact that Northern Ireland had long enjoyed a system of devolution, only recently suspended at the time as a consequence of the escalating sectarian conflicts there, no proposals were advanced in respect of the province.

The initial response to the Kilbrandon report was relatively muted. The commission had been set up by the Labour government against a backdrop of apparent nationalist pressures, but by the time of its report a Conservative government was in power and earlier nationalist gains had been lost. ${ }^{55}$ Indeed, a Scottish Labour MP noted just a few months before the publication of the report that, "This was originally a simple exercise in postponement; it was to get the Labour Government over the difficulty of what to say about nationalist victories at the by-elections. Now...the Nationalists are not a serious proposition." ${ }^{56}$ Upon the report's publication only a brief debate took place in the House of Commons. ${ }^{57}$ However, little more than 3 months after the report's publication, the general election held in February 1974 saw an unprecedented surge in support for the Nationalist parties. The SNP breakthrough was particularly noteworthy, it winning 7 seats on $22 \%$ of the Scottish vote. ${ }^{58}$ In that year's second general election, it would increase its vote further to $30 \%$ of the Scottish total and its parliamentary representation to 11 MPs. ${ }^{59}$ It is against this backdrop that the new Labour government of Harold Wilson included in the Queen's Speech a commitment to "initiate discussions in Scotland and Wales on the Report of the Royal Commission on the Constitution, and [to] bring forward proposals for consideration." 60 The

\footnotetext{
50 Kilbrandon Report (1973: vol.I, para.1119).

51 Kilbrandon Report (1973: vol.I, para.1123).

52 Kilbrandon Report (1973: vol.I, para.1123).

53 Kilbrandon Report (1973: vol.I, para.1123). The matters to be transferred are listed in paras. 1108 \& 1132 .

54 Kilbrandon Report (1973: vol.I, paras.1140-44). This would be accompanied by a reduction in the number of MPs elected by Scotland and Wales, from 71 to 51 and 36 to 31 respectively.

55 The seats gained in Carmarthen and Hamilton by Plaid Cymru and the SNP respectively in earlier byelections had been since retaken by Labour at the 1970 general election, although the SNP did gain a seat (Western Isles) at the same election.

56 John Mackintosh, 'What prospect for a less United Kingdom?', The Times, 30 March 1973, p.18.

57 HC Deb 31 October 1973, vol 863, cc163-75. The report was also briefly debated in the House of Lords. See HL Deb 12 December 1973, vol 347, cc1180-1250.

58 Plaid Cymru also gained two seats in Wales.

59 Plaid Cymru also made a further gain, of one seat.

60 HC Deb 12 March 1974, vol 870, c47.
} 
report again soon formed the subject of debate in the House of Commons in March $1974,{ }^{61}$ Richard Wainwright MP noting when introducing the debate that the recent general election result had "probably rescued [the report] from being just a series of text books." 62 A similar point was made by Vernon Bogdanor in relation to devolution generally, commenting that "Without the rise and electoral success in the 1970s of the [SNP], it is doubtful whether devolution would have assumed as prominent a place on the political agenda." 63 Indeed, just as the Kilbrandon Commission had rejected separatism as an alternative to devolution, the push for devolution to Scotland and Wales was motivated by an explicit "determination to preserve the unity of the United Kingdom." 64

Although the Kilbrandon report had been criticised for the lack of unanimity in its conclusions, supporters of Scottish and Welsh devolution undoubtedly found much in its content which might serve as the basis for moving forward with the devolution agenda. There was broad support from the nationalist parties and the Liberals for implementing devolution on the basis of some of its recommendations. ${ }^{65}$ In an early indication of the kind of arguments which would be heard years later when devolution was finally delivered and again when Scotland launched its independence bid, Plaid Cymru MPs made a point of noting that Wales had never returned a majority of Conservative MPs, ${ }^{66}$ and that a Welsh legislative assembly would serve as a safeguard against the imposition of "anti-working class measures" on the Welsh electorate by Conservative governments. ${ }^{67}$

The prospect of the Kilbrandon Commission's recommendations coming to bear on constitutional change was apparent in the Labour government's publication of a consultative document on devolution during 1974, which led in turn to the white paper Democracy and Devolution: Proposals for Scotland and Wales. ${ }^{68}$ The government endorsed the view of some commission members that it did not "follow that Scotland and Wales must be treated exactly like each other," 69 and the proposals emanating from the white paper reflected this. While expressing an intention to create directly elected assemblies for Scotland and Wales, a prospect unanimously agreed upon-albeit in different forms-by the Kilbrandon Commission's membership, it was envisaged that only the former would be conferred with legislative powers "in fields in which separate Scottish legislation already exists."70 Against the unanimous recommendations of the commission, however, it was

\footnotetext{
61 HC Deb 20 March 1974, vol 870, cc1087-1171.

62 HC Deb 20 March 1974, vol 870, c1088.

63 Bogdanor (1999: 110).

64 Statement by Edmund Dell MP, Paymaster-General, in HC Deb 19 January 1976, vol 903, cc925-1076.

65 See, eg., comments made during debates in the House of Commons by David Steel MP and John Pardoe MP (HC Deb 20 March 1974, vol 870, c1129-1134, 1162-8.

66 Statement by Dafyd Wigley MP (HC Deb 20 March 1974, vol 870, c1161.

67 Statement by D.E. Thomas MP (HC Deb 20 March 1974, vol 870, c1121.

68 UK Government (1974).

69 UK Government (1974).

${ }^{70}$ UK Government (1974).
} 
proposed that the assemblies would be elected on the same basis as the Westminster Parliament, members being returned in single member constituencies. ${ }^{71}$ These proposals to enact some of the key tenets of the Kilbrandon report were developed in greater detail in a subsequent white paper, ${ }^{72}$ finding their way to inclusion within the Scotland and Wales Bill 1976. Then prime minister James Callaghan noted that "The origins of the bill can be found in the Royal Commission on the Constitution", 73 evidently seeing the proposals for Scottish and Welsh devolution as a variant on some of the Kilbrandon recommendations. Although the government was forced to abandon this bill, the broad thrust of its proposals resurfaced in 1978 in the form of the separate Scotland Act and Wales Act. Again, it was proposed to establish a Scottish assembly with legislative powers and a Welsh assembly which would only enjoy executive powers. ${ }^{74}$ While in different circumstances Scottish devolution might have been implemented, given that a majority of Scottish voters backed the creation of a Scottish assembly in 1979s referendum, the insertion into the relevant legislation of a requirement that $40 \%$ of the total electorate supported devolution meant that it failed as the low turnout meant that this had not been achieved. $^{75}$ The lower levels of Welsh support for devolution were apparent in its devastating rejection of a proposed Welsh Assembly. ${ }^{76}$

The election of a Conservative government in 1979 effectively ended any prospects for the devolution of power within the UK for a generation, although the campaign for Scottish devolution, in particular, gathered momentum during the period of Conservative rule, ${ }^{77}$ strengthened in no small part by the fact that Scotland found itself subjected to the policies of a government backed by only a minority of Scottish voters, including most prominently the piloting of the unpopular poll tax in Scotland. During the 1980s and 1990s, Labour's appetite for constitutional reform gradually grew. ${ }^{78}$ Against the backdrop of increased centralisation of power within the state, a 1993 report published by the party advocated strong local and regional government, including the devolution of power to Scotland, Wales and the English regions. ${ }^{79}$ A substantive proposal for a Scottish Parliament was presented by the cross-party Scottish Constitutional Convention in $1995,{ }^{80}$ and Labour and the Liberal Democrats subsequently formed a joint consultative committee on

\footnotetext{
71 UK Government (1974).

72 UK Government (1975). For discussion, see Mbadinuju (1976).

73 HC Deb 13 December 1976, vol 922, cc974-1150.

74 On the acts, see Bogdanor (1999: 183-191).

75 The 'Yes' vote only represented $33 \%$ of the total electorate.

$7680 \%$ of those voting rejected the devolution proposals for Wales.

77 See, eg., Tierney (2013). Following the creation of the Campaign for a Scottish Assembly in 1985, and the publication of a key policy document, 'A Claim of Right for Scotland' in 1988, a cross-party commission of all major parties bar the Conservatives met from 1989 to 1996 to build consensus on the form devolution should take. The resulting document, 'Scotland's Claim, Scotland's Right', would serve as the blueprint for the devolution package eventually introduced by the Blair government.

78 See, eg., Labour Party (1989).

79 Labour Policy Commission (1993). See also Labour Party (1995), Labour Party (1996).

${ }^{80}$ Scottish Constitutional Convention (1995). For discussion, see McFadden (1995).
} 
constitutional reform to attempt to identify common ground on which a package of reform could be built. Its report contained proposals for Scottish and Welsh devolution, ${ }^{81}$ as well as measures for new institutions for the English regions and London. ${ }^{82}$ Recommendations found within the Kilbrandon Commission report were central to the devolution proposals developed during this time and would serve as the basis for the devolution agenda implemented by the Labour government during its first term.

Devolution was finally delivered to Scotland and Wales by the provisions of the Scotland Act 1998 and Government of Wales Act 1998 following referendums in which the populations of the two countries endorsed the creation of a Scottish Parliament and Welsh Assembly respectively, albeit very narrowly in the case of the latter. $^{83}$ Devolution was also restored to Northern Ireland. ${ }^{84}$ The devolved institutions created for Scotland and Wales are not carbon copies of the models envisaged by the majority recommendations of the Kilbrandon Commission. ${ }^{85}$ For example, both the Parliament and Assembly were elected using the AMS electoral system as opposed to the STV model recommended in the Kilbrandon report; their sizes were larger and smaller respectively than proposed by Kilbrandon; ${ }^{86}$ and the scope of their powers also departed somewhat from the Kilbrandon recommendations. ${ }^{87}$ However, the principles underpinning Kilbrandon are very much present in the eventual devolution settlement. Both Scotland and Wales were endowed with a unicameral elected body from which an executive was to be formed. The distinction between the approach to be taken to Scotland and Wales drawn back in 1973 is maintained, Scotland's Parliament being conferred with primary legislative powers from the time of its creation, although the Welsh Assembly was not. However, the recommendation of six members of the Kilbrandon majority that it too enjoy legislative powers was essentially given effect several years later when primary legislative powers were finally devolved to the Assembly. ${ }^{88}$

\footnotetext{
${ }^{81}$ Labour Party \& Liberal Democrats (1997: paras.38-46).

82 Labour Party \& Liberal Democrats (1997: paras.47-51).

$8350.3 \%$ voted 'Yes' to the creation of a Welsh Assembly.

84 However, as Northern Ireland did not feature among the Kilbrandon Commission recommendations, it is not considered here. See, however, Boyle and Hadden (1999).

85 On the systems of devolution introduced by the 1998 legislation, see Hadfield (2011), Leyland (2011: 257-264).

86 The Scottish Parliament comprised 129 members compared to the Welsh Assembly's 60, whereas the majority Kilbrandon report had recommended both comprise 100 members.

87 Schedule 5 of the Scotland Act 1998 listed those 'reserved matters' beyond the Parliament's jurisdiction, these being those areas the nature of which necessitated a UK wide policy, such as national security, defence, international relations, and immigration. Further powers were devolved under the Scotland Act 2012, implementing the recommendations of the Calman Commission. The matters for which responsibility was transferred to the Welsh Assembly were listed in Schedule 2 of the Government of Wales Act 1998 .

88 Government of Wales Act 2006, Schedule 5. The Act essentially implemented the recommendations of the Richard Commission (2004). See further Hadfield (2011: 222-228), Johnson (2006). Following recommendations of the Silk Commission (2012), the Welsh Assembly was granted enhanced powers by the Wales Act 2014.
} 
In it most fundamental respects, a clear line can be drawn from the core recommendations of the Kilbrandon Commission majority report to the systems of Scottish and Welsh devolution introduced and developed from 1998 onwards. The Commission was created at a time when political circumstances favoured the implementation of devolution and until the election of a Conservative government in 1979 intervened, the spirit of its key recommendations came close to realisation. Over the course of two decades its recommendations continued to serve as the basis of the devolution agenda developed by the Labour Party for implementation upon its return to power in 1997. However, an important point must be noted. The initial pressures which gave rise to the creation of the Kilbrandon Commission stemmed from a surge in support for Scottish, and to a lesser extent Welsh, nationalism and a perceived need to further the cause of devolution in order to stem the nationalists' rise. A stated merit of devolution once again in 1997 was that it would strengthen the UK by weakening support for separatist causes. The rise of the SNP in Scotland, the close run independence referendum in 2014, and the party's landslide capture of fifty-six of fifty-nine Scottish seats in the 2015 general election might call into question the extent to which this objective of devolution remains served. It may of course be that recent events represent a false dawn, just as the successes of the SNP in 1974 did. $^{89}$

\section{The English Regions}

Clearly influenced by the sense that the forces mobilising behind calls for devolution in Scotland and Wales were absent in England, neither the majority nor minority report of the Kilbrandon Commission proposed the devolution of legislative powers to the English regions. Instead, the majority proposed for England a scheme of regional coordination in which regional councils would be endowed with merely consultative or advisory functions, as opposed to the legislative powers envisaged for Scotland and Wales. ${ }^{90}$ The bodies would be partly elected by local authorities in the area, and partly appointed by government ministers on the basis of relevant expertise. ${ }^{91}$ By contrast, the minority felt that legislative devolution for Scotland and Wales with no comparable measures for the English regions would produce an intolerable anomaly and injustice, not least in terms of parliamentary representation. ${ }^{92}$ Its dissenting report proposed a scheme of devolution which applied in equal measure to English regions, although under

\footnotetext{
89 Of course, the SNP lost 21 of its 56 seats in the 2017 general election.

90 Kilbrandon Report (1973: vol.I, paras.1195-1209).

91 Kilbrandon Report (1973: vol.I, paras.1195-1209).

92 Kilbrandon Report (1973: vol.II, para.1108. This was essentially a forerunner of the so-called 'West Lothian question', which became particularly pertinent following the devolution of legislative powers to Scotland in 1998. The essence of the grievance was that whereas Scottish MPs would continue to vote on issues at Westminster affecting English regions, English MPs would not enjoy the same right on those issues' application to Scotland where responsibility had been devolved to the Scottish Parliament. Reforms to the House of Commons Standing Orders in 2015 sought to remedy this anomaly by enabling some bills to be certified as applicable only to England (or England and Wales), a veto over the passage of which was conferred upon MPs representing English constituencies.
} 
which the democratically elected regional assemblies proposed would not have legislative competences other than those conferred by delegated powers, instead undertaking a range of executive and administrative functions. ${ }^{93}$ A key distinction between the majority and minority recommendations concerned the areas identified as serving as the geographical basis for English regions. While the minority divided England into five large regions, ${ }^{94}$ the majority envisaged division along lines similar to those used today for administrative purposes. ${ }^{95}$

The lesser level of enthusiasm for English regional devolution present in the Kilbrandon report was evident in the devolution proposals which emerged after the 1974 elections and has been present ever since. The English regions were largely absent from the devolution debate over the period of this parliament, although a consultative paper was published on the subject, ${ }^{96}$ and then Prime Minister James Callaghan did allude to the possibility of devolving powers to these regions somewhere down the line. ${ }^{97}$

When regional devolution for England found itself part of the constitutional reform agenda of the Blair government alongside Scottish and Welsh devolution, the more muted enthusiasm for English devolution present in the Kilbrandon report was again detectable. As per the recommendations of its majority report, the regional assemblies proposed were not envisaged as being conferred with the scale of powers devolved to the Scottish or Welsh institutions. In any event, the NorthEast's rejection of a regional assembly in 2004 essentially put to an end any substantive regional devolution of power to elected assemblies within England and served as a reminder that the, at best, modest levels of support for English regional devolution noted by the Kilbrandon Commission were still present. In later years, any agenda for a uniform, coherent system of elected regional assemblies has been superseded by the more pragmatic phenomenon of localism, which represents a more piecemeal yet pragmatic programme of devolving powers from central government to combined authorities and directly elected mayors to serve broadly economic objectives. ${ }^{98}$ Significantly, localism initiatives tend to centre upon smaller geographic areas than have proposals for English regional assemblies. This may mean that they facilitate an easier fostering of common identity, it having been noted that the large regions suggested as the basis for elected assemblies are to some extent arbitrary and lacking in any shared identity. ${ }^{99}$

\footnotetext{
93 Kilbrandon Report (1973: vol.II, paras.217-232). It was also suggested that the chairs of the assemblies' executive committes would sit in the House of Lords (para.259).

94 Kilbrandon Report (1973: vol.II, para.215).

95 Kilbrandon Report (1973: vol.I, para.211). The key difference is that the majority included London within the proposed South-East region, whereas it has in practice come to be regarded as a region in itself on account of its huge population.

96 UK Government (1976).

97 HC Deb 13 December 1976, vol 922, c984.

98 See Smith \& Wistrich (2014).

99 Kilbrandon Report (1973: Vol.I, para.208).
} 


\section{Wider Constitutional Reform: Missed Opportunities}

The main focus of the Kilbrandon Commission was the devolution of power within the UK, yet its report did touch indirectly upon issues of reform to the electoral system and the House of Lords, albeit within the context of its devolution proposals, both issues which would come to feature to varying degrees within the post-1997 constitutional reform agenda. Given Kilbrandon's acknowledgement of general public dissatisfaction with the operation of democracy and government, however, it is arguable that its failure to probe more closely issues pertaining to electoral reform and reform to the House of Lords represented a missed opportunity to further debate on matters very relevant to questions of democratic representation.

Both majority and minority recommendations suggested that the proposed devolved assemblies be elected using the single transferrable vote method of proportional representation. ${ }^{100}$ This was significant given that with the exception of elections to the suspended Northern Ireland Parliament during its early years, there was no precedent in the UK for using any electoral method other than the first past the post system. However, when Scottish and Welsh devolution was put to referendum in 1979 this was on the basis of the proposed assemblies being elected by the first past the post electoral system in single member constituencies akin to elections to the Westminster Parliament. The eventual introduction of devolution in 1998 was on the basis of bodies elected by the Additional Member System for Scotland and Wales, retaining a degree of a proportional element, although Northern Ireland's Assembly would be elected under the STV to account for the sectarian divisions within the province. However, Northern Ireland aside, there has been no move towards the use of STV and what advances there have been in the campaign for electoral reform have centred upon other electoral models, albeit usually unsuccessfully. Although the Jenkins Commission was established to consider the case for its wider introduction, ${ }^{101}$ no action was taken in response to its conclusions and while the alternative vote system has been utilised for contests such as mayoral contests, its overwhelming rejection in the $2011 \mathrm{AV}$ referendum arguably killed off pressures for more substantive electoral reform for the foreseeable future. While entirely speculative, it is possible that had Kilbrandon given greater attention to the case for electoral reform, it might have garnered more momentum earlier and possibly enjoyed longer term success.

A similar point can be made in respect of House of Lords reform. Although not really discussed by the Commission, one suggestion emanating from its minority was that the leaders of the UK's devolved bodies enjoy membership of the House of Lords. ${ }^{102}$ This proposal has never been taken up seriously, although House of Lords reform has plagued successive governments since the Blair government acted to remove the voting rights of most hereditary peers in the late $1990 \mathrm{~s} .{ }^{103}$ There has not yet been a final resolution of the question of the composition of the second chamber

\footnotetext{
100 Kilbrandon Report (1973: vol.I, paras.788, 1140; vol.II, paras.249-251).

101 See Independent Commission on the Voting System (1998).

102 Kilbrandon Report (1973: vol.II, para.259).

103 Under the terms of the House of Lords Act 1999.
} 
of Parliament, although one possible option is that of a body comprised of the representatives of the UK's nations and regions, ${ }^{104}$ reflecting some of the tone of the proposal mooted in 1973. It is perhaps regrettable that Kilbrandon did not take the opportunity to examine in greater detail the possible relationship between House of Lords reform and the cause of devolution. Again, whether this would have initiated a quicker process towards a final and satisfactory resolution of the composition and status of the House of Lords is highly speculative. Before criticising the apparent limitations of Kilbrandon too harshly, however, it must be recalled that the key trigger event giving rise to its creation was the rise of nationalist pressures and to focus its work almost exclusively on the case for devolution was not an unreasonable or inappropriate approach towards the discharge of its mandate.

\section{Conclusion}

While it is possible to overstate the significance of the Kilbrandon Commission within constitutional reform debates in the UK, its relegation to a mere historical footnote is regrettable. Its report gave the first significant consideration to the case for devolution and advanced proposals which do not diverge radically in the most part from the devolution settlement eventually implemented in 1998. Had devolution been delivered successfully in 1979 as attempted by the Callaghan government, the role of the Kilbrandon Commission within this process would have arguably been considered significant. However, the relegation of the devolution agenda down the political agenda for nearly two decades allowed its role in the devolution debate to be largely forgotten when it found its place firmly back on the agenda following the election of the Blair government in 1997. The Kilbrandon Commission's work should be not given disproportionate credit and, as has been noted, it could arguably have contributed more substantially to wider constitutional reform debates. However, it should be recalled for its importance in helping to get the ball rolling with the development of the devolution agenda in the 1970s which to some extent paved the way for the eventual successful introduction of Scottish and Welsh devolution based on a model not radically removed from that envisaged by some of the Kilbrandon Commission's membership.

Open Access This article is distributed under the terms of the Creative Commons Attribution 4.0 International License (http://creativecommons.org/licenses/by/4.0/), which permits unrestricted use, distribution, and reproduction in any medium, provided you give appropriate credit to the original author(s) and the source, provide a link to the Creative Commons license, and indicate if changes were made.

\section{References}

Bogdanor, V. 1999. Devolution in the United Kingdom. Oxford: Oxford University Press.

Boyle, K., and T. Hadden. 1999. Northern Ireland. In Constitutional reform: The Labour government's constitutional reform agenda, ed. R. Blackburn, and R. Plant, 282-306. London: Longman.

104 See Russell (1999). 
Brazier, R. 1999. The constitution of the United Kingdom. Cambridge Law Journal 58: 96-128.

Brazier, R. 2007. Constitutional reform, 3rd ed. Oxford: Oxford University Press.

Brown, G. 2014. My Scotland, our Britain. London: Simon \& Schuster.

Colley, L. 2009. Britons: Forging the nation 1707-1837. London: Yale University Press.

Commission on Devolution in Wales (Silk Commission). 2012. Empowerment and Responsibility: Financial Powers to Strengthen Wales. Cardiff: Commission on Devolution in Wales.

Curtice, J. 2006. What the people say-If anything. In The english question, ed. R. Hazell, 119-140. Manchester: Manchester University Press.

Daintith, T. 1974. Kilbrandon: The ship that launched a thousand faces? Modern Law Review 47 (5): 544-555.

Devine, T.M. 2012. The Scottish nation: A modern history. London: Penguin.

Evans, A. 2015. Back to the future? Warnings from history for a future UK constitutional convention. The Political Quarterly 86 (1): 24-32.

Evans, J.G. 2006. Devolution in Wales: Claims and responses, 1937-1979. Cardiff: University of Wales Press.

Ferguson, N. 2003. Empire: How Britain made the modern world. London: Penguin.

Hadfield, B. 2003. The United Kingdom as a territorial state. In The British constitution in the twentieth century, ed. V. Bogdanor, 585-630. Oxford: Oxford University Press.

Hadfield, B. 2011. Devolution: A national conversation. In The changing constitution, 7th ed, ed. J. Jowell, and D. Oliver, 216-232. Oxford: OUP.

Independent Commission on the Voting System. 1998. Report of the independent commission on the voting system. London: The Stationery Office.

Johnson, N., and The Government of Wales Act. 2006. Welsh devolution still a process and not an event? Web Journal of Current Legal Issues 2007: 4.

Killeen, R. 2012. Ireland: Land, people, history. London: Constable \& Robinson.

Labour Party. 1989. Meet the challenge: Make the change. London: Labour Party.

Labour Party. 1995. A choice for England. London: Labour Party.

Labour Party. 1996. A new voice for England's regions. London: Labour Party.

Labour Policy Commission. 1993. A new agenda for democracy. London: Labour Party.

Labour Party/Liberal Democrats. 1997. Report of the joint consultative committee on constitutional reform. London: Labour Party/Liberal Democrats.

Leicester, G. 1999. Scottish and welsh devolution. In Constitutional reform: The labour government's constitutional reform agenda, ed. R. Blackburn, and R. Plant, 251-263. London: Longman.

Leyland, P. 2011. The multifaceted dynamics of U.K. devolution. International Constitutional Law Journal 9 (1): 251-273.

Mbadinuju, C.C. 1976. Devolution: The 1975 white paper. The Political Quarterly 47 (3): 286-296.

McFadden, J. 1995. The Scottish Constitutional Convention. Public Law: 215-223.

McKay Commission. 2013. Report of the Commission on the Consequences of Devolution for the House of Commons. www.tmc.independent.gov.uk.

O'Neill, M. 2004. State building and national integration in Britain. In Devolution and British politics, ed. M. O’Neill, 13-31. London: Pearson.

Richard Commission. 2004. Report of the Richard Commission on the Powers and Electoral Arrangements of the National Assembly for Wales. Cardiff: National Assembly for Wales.

Royal Commission on the Constitution (Kilbrandon Commission). 1973. Report of the Royal Commission on the Constitution (Kilbrandon Report). London: HMSO.

Russell, M. 1999. Representing the Nations and Regions in a New Upper House. London: Constitution Unit.

Scottish Constitutional Convention. 1988. A Claim of Right for Scotland. Edinburgh: Convention of Scottish Local Authorities.

Scottish Constitutional Convention. 1995. Scotland's parliament: Scotland's right. Edinburgh: Convention of Scottish Local Authorities.

Smith, D., and E. Wistrich. 2014. Devolution and localism in England. Farnham: Ashgate.

Sumption, Lord. 2014. The disunited kingdom: England, Ireland and Scotland. Cambridge Journal of International and Comparative Law 3 (1): 139-158.

Tierney, S. 2013. The three hundred and seven year itch: Scotland the 2014 independence campaign. In The British constitution: Continuity and change, ed. M. Qvortrup, 141-152. Oxford: Hart.

UK Government. 1974. Democracy and devolution: Proposals for Scotland and Wales. London: HMSO.

UK Government. 1975. Our changing democracy: Devolution to Scotland and Wales. London: HMSO.

UK Government. 1976. Devolution: The english dimension. London: HMSO.

UK Government. 2002. Your region, your choice. London: HMSO. 